\title{
Adult male coatis play with a band of juveniles
}

\author{
Logan, CJ. ${ }^{a *}$ and Longino, $J T .^{b}$ \\ ${ }^{a}$ SAGE Center for the Study of the Mind, Department of Psychological and Brain Sciences, \\ University of California, Santa Barbara, CA 93106, U.S.A. \\ 'Department of Biology, University of Utah, 257 South 1400 East, Salt Lake City, Utah, 84112, U.S.A. \\ *e-mail: itsme@corinalogan.com \\ Received February 14, 2012 - Accepted May 18, 2012 - Distributed May 31, 2013
}

\begin{abstract}
This study examined the play behaviour in one group of coatis (Nasua narica) at La Selva Biological Station in Costa Rica. We incidentally found adult males playing with juvenile coatis, and conducted post-hoc analyses to investigate this interaction. Coati groups consist of adult females and juveniles of both sexes until male juveniles reach two years of age and leave the band to become solitary. Adult males only tolerate juveniles for a brief period during breeding season when the males court females to mate. Outside of the breeding season, adult males are known to prey on juveniles. In this study, when adult males were present with the band, play occurred more than was expected by chance, and adult males engaged in many of these play bouts. Because the mechanisms driving infanticidal behaviour are not well understood, and adult male coatis show a range of behaviours from infanticide to highly affiliative interactions with juveniles, using coatis as a model system may elucidate mechanisms underlying infanticide.
\end{abstract}

Keywords: Costa Rica, Nasua narica, play, Procyonidae, white-nosed coati.

\section{Quatis machos adultos brincam com um bando de quatis jovens}

\begin{abstract}
Resumo
Este estudo analisou o comportamento da brincadeira em um grupo de quatis (Nasua narica) em La Selva Biological Station, na Costa Rica. Incidentalmente, foram encontrados machos adultos brincando com quatis em fase juvenil, sendo então conduzidas análises post hoc para investigar essa interação. Os grupos de quatis consistem de fêmeas adultas e jovens de ambos os sexos, até os machos jovens atingirem dois anos de idade e deixar o bando para se tornarem solitários. Os machos adultos toleram os machos jovens apenas por um breve período, durante a época de reprodução, quando os machos cortejam as fêmeas para o acasalamento. Fora da época de reprodução, os machos adultos são conhecidos por caçar os machos jovens. Neste estudo, quando os machos adultos estavam presentes no bando, o jogo ocorreu mais do que era esperado nessas condições, sendo que os machos adultos mostraram-se envolvidos em muitas dessas lutas do jogar. Na medida em que os mecanismos de condução do comportamento infanticida não são bem compreendidos e desde que quatis machos adultos apresentam uma gama de comportamentos de infanticídio em meio às interações de filiação com os machos jovens, usando-se quatis como um sistema modelo, podem-se elucidar os mecanismos subjacentes ao infanticídio.
\end{abstract}

Palavras-chave: Costa Rica, Nasua narica, jogo, Procyonidae, quati-de-nariz branco.

\section{Introduction}

The white-nosed coati (Nasua narica Linnaeus, 1766), is the most social and least territorial member of the Procyonidae (Beisiegel, 2001; Bekoff et al., 1984; Gompper, 1997; Kaufmann, 1962; Russell, 1979; Wilson and Ruff, 1999). It is a common and widespread diurnal mammal, occurring throughout the Neotropics (Wainwright, 2002; Wilson and Ruff, 1999). The coati social structure includes bands of adult females with juveniles of both sexes. At the end of two years of age, males leave the group to become solitary, and reach sexual maturity at three years of age. One and sometimes two adult males are permitted to join

a band for an annual mating season of about two weeks (Kaufmann, 1962; Russell, 1979, 1981; Wainwright, 2002; Wilson and Ruff, 1999). Outside of the breeding season, adult male coatis are known to attack bands (Russell, 1996) and prey on juveniles (Russell, 1981). Reports of adult males engaging in friendly interactions with juveniles are rare, but do exist (Kaufmann, 1962; Gompper and Krinsley, 1992; Russell, 1979,1981, 1983). Given the coati social structure, we predict that juveniles will play more with juveniles than with adult female band members, and that no play will occur between adult males and juveniles. 


\section{Methods}

Research was conducted at the Organization for Tropical Studies' La Selva Biological Station $\left(10^{\circ} 26^{\prime} \mathrm{N}\right.$ and $83^{\circ}$ 59' W) in Costa Rica between 0500 and 1800 from late March to early June 2004. CJL located coatis by walking the grounds at La Selva and responding to reported sightings by other visitors to the station. One band of nine juveniles and two adult males were encountered and followed from a distance of one to $20 \mathrm{~m}$. The ages of the two adult males were unknown: perhaps they were sub-adults (two years old) or, more likely, adults (three years or older) because of their larger body size and descended testicles, which indicate adult status (Kaufmann, 1962; Russell, 1979). Juveniles were identified by their smaller size and were assumed to be one year old. No adult females were seen during the study and were assumed to be away for their eight-week nesting season. One juvenile disappeared after 28 days.

Observation sessions $(\mathrm{N}=15)$, conducted by CJL, were divided into five-minute sample intervals $(\mathrm{N}=764)$ and lasted from 30 minutes to 10 hours on 14 different days. All individuals that could be seen at one time were the focal group. We were unable to individually identify subjects, therefore, the one-zero sampling method was employed for data collection, which included scanning and recording continuously the presence of behaviours (play, foraging, traveling, and resting) in five-minute intervals. Each time interval was scored with a one or a zero, depending on whether the target behaviour was observed or not, respectively (Altmann, 1974; Martin and Bateson, 2007). Multiple behaviours could occur in the same time interval. This method overestimates durations and underestimates frequencies of certain types of behaviour; however it is useful for a behaviour such as play which is sporadic, brief, begins and ends rapidly, and is often difficult to distinguish between separate bouts. It is also a practical way of recording many categories of behaviour at once and it is a suitable measure for amounts of behaviour (Martin and Bateson, 2007). Additional play data was collected using ad libitum sampling including the age classes of the players and whether an adult was present. Play behaviour was defined as spontaneous and voluntary; not carried out in a fully functional way given its context because it "includes elements...that do not contribute to current survival"; differing from the "serious" form of the same movement by being exaggerated, awkward, or having a modified form or sequence; repeated enough to make it a feature of the behavioural repertoire and not a rare behaviour; and initiated when subjects are in a "relaxed" state (i.e., not hungry, engaged in intense competition, or overly stressed; Burghardt, 2005, p. 71-78); and can include object play, social play, or solitary play. Play could occur more than once in an interval and could contain multiple groups of individuals playing at the same time. A play bout is defined as one or more sequential intervals in which play is present, separated by at least one interval without play. This counts the number of play bouts at the group level since we were not able to record the durations of individual play bouts without individually marking the coatis. To determine who plays with whom, each interval was scored for presence or absence of juvenile play and presence or absence of adult play. To determine whether play increases in the presence of an adult, each five-minute sample interval was scored for presence of play and presence of an adult. A chi-square goodness-of-fit test was used to determine whether juvenile play increased or decreased in the presence of adult males.

\section{Results}

Play was present in $22 \%$ of all of the intervals of observation. Play fighting was the predominant type of play (and what we refer to as 'play' in this paper) and involved biting, rolling, chasing, standing facing each other, tackling, kicking, jumping on top of each other, jumping at each other (sometimes simultaneously), squeaking, lunging, grabbing, displaying open mouths to each other, and role reversals. Juvenile-juvenile and juvenile-adult play interactions appeared to be similar. There were four bouts of object play where a single juvenile played with a liana in a tree. The actions involved grabbing the liana with the front paws and chewing on it. All four bouts occurred on the same day and within 30 minutes of each other. It was unclear whether the four bouts were by the same individual or multiple individuals.

The band of juveniles was observed alone in $38 \%$ of the intervals, adult males alone in $2 \%$, and adult males together with juveniles in $60 \%$. There were 39 discrete play bouts that occurred on 12 different days. A bout consisted of intervals in which play occurred that were separated by at least one interval in which there was no play. There were no adult females with the band of juveniles, therefore no play was expected between juveniles and adults because the adults that occasionally appeared with the band were adult males. Surprisingly, adult males were present with the band of juveniles during 24 play bouts and, of these, played with juveniles in 22. Therefore, juveniles played with adult males more than expected.

A post-hoc analysis was conducted to determine whether there was more play in the presence of adult males or if their presence decreased play behaviour in the band. Adult males were present with the band of juveniles for 24 bouts (each bout was separated by interval(s) in which there was no adult male presence, and could contain multiple play bouts) on 13 different days. Of these, adult males played with juveniles significantly more than expected by chance $\left(\chi^{2}=16.67, \mathrm{p}<0.001, \mathrm{~N}=22\right.$ bouts of male presence and playing, $\mathrm{N}=2$ bouts of male presence and not playing).

\section{Discussion}

Affiliative interactions between adult male and juvenile coatis are rare, even during the mating season when adult males join bands and interact with the adult females using behaviours including mutual grooming and playing (Kaufmann, 1962; Russell, 1979). Gompper and Krinsley 
(1992) observed adult males in contact with bands and close to juveniles, but there was no play activity. Russell (1979) also noted adult males associating with bands outside of breeding season, yet no play was mentioned. It is known that bands composed only of juveniles exist during the birthing season, however only one friendly encounter between this type of band and an adult male has been noted (Russell, 1981, 1983).

In this study, almost all interactions between the band of juveniles and the two adult males were friendly. Juveniles played more in the presence of an adult male, and adult males played with juveniles in many of these bouts. Perhaps the adult males in this study were tolerated because they were kin: either a recently dispersed member of the band or their father. Individuals may recognise and tolerate familiar individuals based on natal band membership or kinship.

Adult male interactions with juveniles range from infanticide to tolerance to active affiliation (play). What drives these differences is unknown. The benefits of infanticide and the mechanisms of infanticide prevention are not well understood at a broad level (Ebensperger, 1998). The coati's high intra-specific variation in infanticidal behaviour makes for an excellent model system in which to empirically investigate infanticidal benefits and prevention mechanisms through long-term studies in which genetic relationships are known.

Acknowledgements - CJL thanks Christopher Montero, Anja Schiller, Charissa Young, Joel Sáenz, Ben Hirsch, Marek Spinka, Katherine McFadden, Heather Heying, Rebecca Bixby, Martin Dohrn, John Pepper, and Dieter Lukas who were beneficial resources; and Pat Bateson for comments on a draft of this manuscript. This research was partially supported by The Evergreen State College Foundation Activity Grant and The Explorers Club Youth Activity Grant.

\section{References}

ALTMANN, J., 1974. Observational study of behaviour: sampling methods. Behaviour, vol. 49, p. 227-267. PMid:4597405. http:// dx.doi.org/10.1163/156853974X00534

BEISIEGEL, BM., 2001. Notes on the coati, Nasua narica (Carnivora: Procyonidae) in an Atlantic forest area. Revista Brasileira de Biologia = Brazilian Journal of Biology, vol. 61, p. 689-692. PMid:12071327. http://dx.doi.org/10.1590/S151969842001000400020

BEKOFF, M., DANIELS, TJ. and GITTLEMAN, JL., 1984. Life history patterns and the comparative social ecology of carnivores. Annual Review of Ecology and Systematics, vol. 15, p. 191-232. http://dx.doi.org/10.1146/annurev.es.15.110184.001203

BURGHARDT, GM., 2005. The Genesis of Animal Play: Testing the Limits. Cambridge: MIT Press.

EBENSPERGER, LA., 1998. Strategies and counterstrategies to infanticide in mammals. Biological Reviews, vol. 73, p. 321-346. http://dx.doi.org/10.1017/S0006323198005209

GOMPPER, ME., 1997. Population ecology of the white-nosed coati (Nasua narica) on Barro Colorado Island, Panama. Journal of Zoology, vol. 241, p. 441-455. http://dx.doi.org/10.1111/j.1469-7998.1997. tb04836.x

GOMPPER, ME. and KRINSLEY, JS., 1992. Variation in social behaviour of adult male coatis (Nasua narica) in Panama. Biotropica, vol. 24, p. 216-219. http://dx.doi.org/10.2307/2388677

KAUFMANN, JH., 1962. Ecology and social behavior of the coati on Barro Colorado Island, Panama. University of California Publications in Zoology, vol. 60, p. 95-222.

MARTIN, P. and BATESON, PPG., 2007. Measuring Behaviour. 3rd ed. Cambridge: Cambridge University Press.

RUSSELL, JK., 1979. Reciprocity in the social behavior of coatis (Nasua narica). Chapel Hill: University of North Carolina. PhD dissertation.

-, 1996. Timing of reproduction by coatis (Nasua narica) in relation to fluctuations in food resources. In: LEIGH JUNIOR, EG., RAND, AS. and WINDSOR, DM. (Eds.). The ecology of a tropical forest. 2. ed. Washington: Smithsonian Institution Press. p. 413-431.

-, 1981. Exclusion of adult male coatis from social groups: protection from predation. Journal of Mammalogy, vol. 62, p. 206-208. http://dx.doi.org/10.2307/1380499

-, 1983. Altruism in coati bands: nepotism or reciprocity? In WASSER, SK. (Ed.). Social Behavior of Female Vertebrates. New York: Academic Press. p. 263-290.

WAINWRIGHT, M., 2002. The Natural History of Costa Rican Mammals. Miami: Zona Tropical.

WILSON, DE. and RUFF, S., 1999. White-nosed coati: Nasua narica. In WILSON, DE. and RUFF, S. (Eds.). The Smithsonian Book of North American Mammals. Washington: Smithsonian Institution Press. p. 223-225. 